SGientiæ studia, São Paulo, v. 12, n. 3, p. 4,39-64, 2014

\title{
st \\ O Trieb de Freud como instinto 2: agressividade e autodestrutividade
}

\author{
Richard Theisen Simanke
}

\begin{abstract}
药
RESUMO

O conceito freudiano de impulso ou instinto (Trieb) é reconhecidamente um dos conceitos mais fundamentais da psicanálise. No entanto, seu sentido ainda é objeto de controvérsia. Originalmente definido por Freud num sentido biológico ou quase biológico, sua recepção em muitas das diversas tradições pósfreudianas tendeu, frequentemente, a recusar essa filiação epistemológica inicial. Um dos sinais dessa reorientação doutrinária é a recusa da tradução de Trieb por "instinto" e a preferência pelo neologismo "pulsão", de origem francesa e comum na literatura psicanalítica escrita em várias das línguas neolatinas, inclusive em português. O objetivo deste artigo é criticar essa tendência. Para tanto, são examinados os principais argumentos normalmente apresentados contra uma visão biológica do Trieb freudiano, a saber: 1) a alternativa terminológica entre os termos alemães Trieb e Instinkt e o modo como estes são utilizados por Freud; 2) a crítica freudiana de uma redução da sexualidade humana à função reprodutiva; 3) o conceito de Todestrieb (instinto ou pulsão de morte) formulado por Freud por volta de 1920 e central na etapa final de seu pensamento. Procura-se argumentar que essas formulações não impedem uma interpretação biológica do conceito de Trieb. Essa interpretação, por sua vez, abre uma via de diálogo entre a psicanálise e a biologia, a qual é também enfática e explicitamente defendida por Freud. Uma série de formulações oriundas, sobretudo, do campo da biologia evolucionária de orientação neodarwinista e da sociobiologia - são discutidas, com o intuito de argumentar pela sua compatibilidade, se não pela sua convergência, com as teses freudianas. A primeira parte deste trabalho introduziu a questão e também abordou o problema da relação entre sexualidade e reprodução na psicanálise e na biologia. Esta segunda parte está dedicada ao problema da agressividade e da autodestrutividade nessas duas áreas do conhecimento.
\end{abstract}

Palavras-Ghave • Freud. Psicanálise. Metapsicologia. Instinto. Pulsão. Biologia. Morte. Sexualidade.

\section{INTRODUÇÃO}

Na primeira parte deste trabalho (Simanke, 2014), empreendeu-se uma discussão geral do emprego freudiano do conceito de instinto ou impulso (Trieb) com o intuito de examinar criticamente a postura teórica dentro do campo psicanalítico que defende o distanciamento entre a noção freudiana e as concepções biológicas do instinto. Foi discutida, ainda, a crítica freudiana da redução da sexualidade à reprodução, argumentando-se que essa crítica não inviabiliza uma interpretação do Trieb sexual de Freud como instinto sexual. 
Esta segunda parte dá prosseguimento ao trabalho, examinando duas outras ordens de argumentos que supostamente afastariam Freud da biologia, a saber, sua abordagem da agressividade, sobretudo em suas manifestações excessivas e patológicas, e sua ideia de que há uma tendência inerente aos organismos - e, portanto, à vida mental-que os conduz a sua própria aniquilação. A abordagem freudiana de ambos os problemas, a partir de 1920, apelou decisivamente para a ideia de que haveria um instinto de morte (Todestrieb) em ação no psiquismo humano e no âmbito da vida em geral. Essa hipótese desencadeou considerável reação contrária quando da sua formulação original (cf. Foxe, 1943; Wilbur, 19411a, 194.1b), resistência que ainda se manifesta mais contemporaneamente, não apenas com relação ao instinto de morte e sua interpretação biológica, mas também com relação à utilização do conceito de instinto (Trieb) em psicanálise como tal (cf. Slavin \& Kriegman, 1988; Blanco, 2005; Frank, 2003).

Na perspectiva freudiana, contudo, essa hipótese não contradiria o conhecimento biológico. Ele chega a essa conclusão após examinar detidamente as teorias biológicas da época sobre a questão: "Não se cumpriu nossa expectativa de que a biologia haveria de descartar de saída o reconhecimento do instinto de morte" (Freud, 1998 [1920], p. 48). Trata-se agora, assim, de examinar, à luz de concepções mais contemporâneas, até que ponto tais concepções de fato requereriam um afastamento da psicanálise com relação à biologia e uma interpretação não biológica dos conceitos freudianos, na contramão, inclusive, daquilo que o próprio Freud defendeu.

\section{O Trieb COMO INSTINTO AGRESSIVO}

Freud só começou a falar mais explicitamente de um instinto agressivo (Agressionstrieb) na esteira da formulação da segunda dualidade instintual. Esta última - com a introdução do conceito de instinto de morte, que pode também se exteriorizar como agressão - colocou a agressividade num outro patamar de importância na economia psíquica. Mas isso não quer dizer que os impulsos agressivos não fossem, antes disso, um problema intensivamente trabalhado no âmbito da metapsicologia freudiana. No quadro da primeira teoria dos instintos, Freud trabalhou a agressão em basicamente dois contextos. $O$ primeiro refere-se às formas erotizadas da agressão, nas quais a transformação de amor em ódio e o posterior retorno contra si mesmo dão origem respectivamente ao sadismo e ao masoquismo:

Quanto ao par de opostos sadismo-masoquismo o processo se pode apresentar da seguinte maneira: (a) O sadismo consiste em uma ação violenta, numa afirmação de poder dirigida a outra pessoa como objeto. (b) Esse objeto é abandona- 
do e substituído pela própria pessoa (...). (c) Busca-se de novo como objeto uma pessoa alheia que, em consequência da mudança ocorrida com a meta, tem que assumir o papel de sujeito. O caso "c" é o do masoquismo, como comumente se chama. A satisfação é obtida, também nele, pela via do sadismo originário, enquanto que o eu passivo é transposto, em fantasia, a sua posição anterior, que agora é deixada ao sujeito alheio (Freud, 1998 [1915], p. 123).

O segundo é o da agressividade adaptativa e alodirigida, creditada como uma manifestação dos instintos egóicos de autoconservação - por exemplo, quando Freud afirma que "os verdadeiros protótipos da relação de ódio não provêm da vida sexual, mas da luta do eu por sua conservação e afirmação" (Freud, 1998 [1915], p. 131).

Esse segundo sentido não coloca muitas dificuldades para sua caracterização ou justificação em termos biológicos. Parece evidente que um comportamento agressivo pode trazer vantagens adaptativas e ser favorecido pela seleção natural ao longo da evolução da espécie. De fato, Lorenz, em sua abordagem etológica da agressão intraespecífica - isto é, "do instinto de combate do animal e do homem, dirigido contra seu próprio congênere" (Lorenz, 1969 [1963], p. 5) -, parte justamente da percepção da convergência entre os resultados da biologia do comportamento e da psicanálise:

Uma discussão da teoria das pulsões de Freud me revelou uma concordância inesperada de certos resultados da psicanálise com a fisiologia do comportamento, concordância significativa precisamente em razão das diferenças entre as duas disciplinas quanto a seus modos de abordar o problema, seus métodos e, sobretudo, sua base indutiva (Lorenz, 1969 [1963], p. 6). ${ }^{\mathbf{1}}$

Lorenz faz uma ressalva a essa aproximação: ele discorda do conceito freudiano de uma pulsão ou instinto de morte. (O fato de que a abordagem da agressão não exija, de fato, uma hipótese tal como o Todestrieb freudiano é uma das razões pelas quais os dois temas são tratados separadamente aqui). A recusa desse conceito está de acordo com seu objetivo de dissipar a aura demoníaca que cerca o comportamento agressivo (o título original de seu livro é, literalmente, $O$ assim chamado mal: para uma história natural da agressão) e apresentá-lo como uma forma de ação a serviço da sobrevivência e, portanto, convergindo com a meta geral da conservação. Essa meta, como se viu acima, é característica da primeira teoria freudiana dos instintos, embora venha a ser fortemente restringida - ou, pelo menos, redefinida - na segunda. Seria, portanto,

1 Lorenz, nessas passagens, utiliza alternadamente os termos Trieb e Instinkt (ver citação seguinte), razão pela qual reintroduzi aqui o neologismo "pulsão" para manter essa distinção. Mas já vimos acima que ele considera ambos os termos adequados para exprimir o conceito biológico de instinto ou ação instintiva. 
com a primeira dualidade instintual freudiana que a teoria de Lorenz apresentaria maior afinidade. A segunda, juntamente com o conceito de instinto de morte, teria que ser recusada:

Aos olhos do fisiólogo do comportamento, essa hipótese [da pulsão de morte freudiana] estrangeira à biologia não parece apenas inútil, mas também falsa. A agressividade, cujos efeitos são frequentemente identificados aos da pulsão de morte, é um instinto como todos os outros e, em condições naturais, ele contribui, como todos os outros, para a conservação da vida e da espécie. No homem que, por sua própria ação, transformou rapidamente suas condições de vida, o instinto de agressão produz frequentemente efeitos nocivos, mas os outros instintos têm resultados análogos, embora menos dramáticos (Lorenz, 1969 [1963], p. 6).

Como se vê, Lorenz tem uma visão apenas parcialmente naturalista da agressão humana. Isso resulta de sua visão geral do instinto agressivo. Para ele, a agressividade é o resultado de um instinto simples, uma disposição comportamental herdada, que se manifesta como um impulso para a realização desse tipo de comportamento. Esse impulso gera uma tensão crescente que, em princípio, precisa ser descarregada pela ação - nesse caso, pela agressão efetiva. Nas espécies em que a agressividade excessiva pode produzir efeitos nocivos - em predadores particularmente bem armados, por exemplo, nos quais as mesmas armas empregadas para o abate de suas presas podem produzir efeitos devastadores nos membros da própria espécie -, a seleção natural teria moldado, ao longo da evolução, mecanismos inibitórios para a agressão intraespecífica (o caso dos sinais de submissão empregados pelos lobos é exemplar quanto a esse aspecto). No caso da espécie humana - cujo armamento natural (presas, garras, etc.) é relativamente inofensivo -, essas inibições teriam sido desnecessárias durante boa parte de sua história evolutiva. No entanto, a evolução cultural recente da espécie a teria dotado de um armamento infinitamente mais perigoso, num ritmo rápido demais para permitir o surgimento das inibições biológicas capazes de limitar a agressão. Daí o caráter destrutivo e desadaptativo da agressividade humana, que Freud teria julgado necessário explicar pela postulação de um instinto de destruição (Destruktions trieb) ou de um instinto de morte (Todestrieb) específico. O caráter mortífero da agressão humana não derivaria, assim, de sua base instintiva, mas das condições trazidas pela cultura. Esta foi, de fato, a tese desenvolvida e levada às últimas consequências por Erich Fromm, em seu livro Anatomia da destrutividade humana (Fromm, 1973). Segundo Fromm, a espécie humana apresentaria formas patologicamente exageradas de agressividade, resultantes da desnaturalização do contexto em que o comportamento 
agressivo ocorre: não mais um ambiente natural, no sentido ecológico da palavra, mas um meio artificial, social e cultural, constituído por um processo de ruptura com relação ao primeiro.

Esse modelo explicativo do tipo impulso/ tensão/ descarga foi criticado por Wilson que, significativamente, o atribuiu tanto a Freud, quanto a Fromm e Lorenz. ${ }^{2}$ Inicialmente, ele afirma, da forma mais taxativa possível, que há evidências incontestáveis de que a agressão humana possua determinantes inatos. O que, exatamente, no comportamento agressivo, é inato e em que medida herança e aprendizagem, natureza e cultura comparecem na sua determinação é discutido ao longo de sua argumentação. A própria universalidade das formas culturalmente instituídas de controle da agressividade é invocada como argumento a favor de seu caráter inato:

São os seres humanos inatamente agressivos? (...) A resposta é sim. Ao longo da história, as guerras, que não passam de técnicas de agressão mais organizadas, têm sido endêmicas em todas as formas de sociedade, desde os bandos de caçadores-coletores até os Estados industrializados. (...) Virtualmente todas as sociedades criaram sanções elaboradas contra o estupro, a extorsão e o assassinato, e regulamentaram seu comércio diário através de direitos aduaneiros e leis complexas destinadas a minimizar as formas de conflito mais sutis, embora inevitáveis. (...) Somente redefinindo as palavras ‘inatismo' e 'agressão' a ponto de tornálas inúteis, poderíamos corretamente dizer que a agressividade humana não é inata (Wilson, 1981 [1978], p. 99).

Partindo dessa sua concepção, o autor identifica em Lorenz e em Freud uma mesma teoria do caráter instintivo (inato) da agressividade humana, a qual criticará em seguida. Essa teoria específica é o que foi designado acima como o modelo de impulso/ tensão/descarga. Uma das consequências desse modelo seria o diagnóstico pessimista de que a agressão humana é uma forma de comportamento hipertrófica e desprovida dos necessários controles inibitórios para ser eficientemente adaptativa. Esse pessimismo se manifestaria na teoria de Lorenz nos termos vistos acima e, em Freud, presumivelmente, pela introdução do conceito de instinto de morte em sua teoria dos instintos. Wilson não se detém sobre esse ponto, mas ele parece concordar com a visão de Lorenz sobre a sua proximidade com Freud, já que endereça a ambos a mesma espécie de crítica. Já a teoria proposta por Fromm seria diferente por não se deter tanto na questão da base instintiva da agressividade, mas compartilharia com Lorenz e Freud 
a visão pessimista quanto ao caráter excessivo da agressividade. Fromm, na verdade, levaria essa visão a um ponto extremo, utilizando-a inclusive como argumento para sua defesa da natureza não biológica ou, ao menos, não totalmente biológica da agressão humana:

Freud interpretou o comportamento dos seres humanos como o resultado de um impulso que constantemente procura libertação. Konrad Lorenz, em seu livro Agressão, modernizou esse ponto de vista com novos dados provenientes de estudos sobre o comportamento animal. Concluiu que os seres humanos compartilham um instinto geral de comportamento agressivo com outras espécies animais. Esse impulso deve ser aliviado de algum modo (...). Erich Fromm (...) adotou um ponto de vista diferente e ainda mais pessimista: segundo ele, o homem está sujeito a um instinto de morte sem paralelo comumente conduzindo a formas patológicas de agressão que ultrapassam aquelas encontradas em animais (Wilson, 1981[1978], p. 101).

A sua crítica a esse modelo recorre a diversos argumentos. Em primeiro lugar, ela tem como alvo as consequências previstas pelo mesmo: Wilson argumenta que a agressividade humana está longe de ser excessiva, quando considerada comparativamente com outras formas de comportamento agressivo no mundo animal. Essa seria uma visão popular e não científica da agressividade humana. Como acontece frequentemente, essa visão popular teria sido contaminada por amplas doses de antropocentrismo, em que aquilo que diz respeito mais diretamente à espécie humana é contemplado como que por uma lente de aumento. O senso comum teria sido assim, a esse respeito, influenciado por certa vulgarização das ideias de pesquisadores como Freud e Lorenz:

Jornalistas seguidores de Lorenz e Fromm descreveram, no passado, a humanidade como uma espécie sanguinária não alcançada pelos poderes explicativos da ciência. Contudo, isso também está errado. Embora marcadamente predispostos à agressividade, estamos longe de sermos animais excessivamente violentos. Estudos recentes de hienas, leões e macacos langures, só para tomar três espécies familiares, revelaram que os indivíduos empenham-se em lutas fatais, infanticídios e até mesmo canibalismo numa proporção muito maior que aquela encontrada nas sociedades humanas. Num levantamento do número de assassinatos cometidos anualmente por cada mil indivíduos, os seres humanos estão bem abaixo na lista das criaturas violentamente agressivas (...). Suspeito que se babuínos hamadríadas tivessem armas nucleares destruiriam o mundo numa se- 
mana. E comparados às formigas, que cometem assassinatos e entregam-se a escaramuças e batalhas acirradas como atividade rotineira, os homens não são mais que tranquilos pacifistas (Wilson, 1981 [1978], p. 103-5).

Mais especificamente, essa crítica visa outras previsões empíricas que se podem extrair do modelo impulso/ tensão/ descarga. Por exemplo, se o modelo fosse verdadeiro, deveríamos esperar que formas regulares e culturalmente estabelecidas para a descarga da agressividade (esportes competitivos e violentos, por exemplo) tivessem seu interesse diminuído em épocas em que outras formas de agressão socialmente organizada estivessem disponíveis e em primeiro plano - períodos de guerra ou revolução social, por exemplo. No entanto, o que se observa é exatamente o contrário. Mas além dessas objeções empíricas contingentes, há um argumento conceitual e mais decisivo. Para Wilson, a agressão é uma forma complexa de comportamento social e não pode ser reduzida à manifestação de um impulso simples que possuísse uma base biológica pontual e uniforme (o que não quer dizer que não possua nenhuma base biológica, evidentemente). São exatamente essas formas complexas de comportamento social, aliás, que constituem o campo de investigação reivindicado pela sociobiologia.

Ambas essas interpretações [de Freud e de Lorenz] estão erradas. Como tantas outras formas de comportamento e de "instinto", a agressão em qualquer espécie é, na realidade, um conjunto mal definido de respostas diferentes com controles separados no sistema nervoso. Nada menos que sete categorias podem ser distinguidas: a defesa e conquista de território, a afirmação de dominância nos grupos bem organizados, a agressão sexual, os atos de hostilidade pelos quais o desmame é completado, a agressão contra as presas, os contra-ataques defensivos contra predadores e a agressão moralista e disciplinar usada para fazer cumprir as regras da sociedade (Wilson, 1981 [1978], p. 101-2).

O termo "instinto" aparece, nessa passagem, grafado entre aspas, justamente porque os sociobiólogos são bastantes críticos da ideia de que haveria uma determinação hereditária simples para os comportamentos sociais cuja evolução biológica eles se dedicam a investigar. Na medida em que o termo "instinto" apresente essa conotação, ele se torna suspeito e tende a ser evitado, havendo inclusive quem defenda a sua total abolição, tanto na psicologia e nas ciências do comportamento em geral, quanto na própria biologia (cf. Moltz, 1965; Whalen, 1971; Barnett, 1972; Bateson, 2000). Mas essa não é uma posição unânime e, seja como for, não há problemas em manter-se o uso do termo como uma forma abreviada de designar o conjunto dos determinantes inatos de um dado comportamento, por mais complexos e diversificados que estes 
sejam. É preciso, no entanto, precaver-se de considerar o instinto como uma característica fenotípica simples, controlada por mecanismos cerebrais localizados e, muito menos, por um conjunto restrito de genes, que a determinaria de forma autônoma e exclusiva, isto é, sem interação com outras partes do genoma e sem a intermediação de processos epigenéticos elaborados.

É interessante observar que entre as diversas e heterogêneas formas de agressão identificadas pelo pesquisador existem várias que foram efetivamente pesquisadas por Freud: a agressão sexual (a qual pode incluir as formas erotizadas que se apresentam como sadismo), a afirmação de dominância (no estabelecimento de relações assimétricas de poder, como no caso dos condutores das massas) e a agressão moralista e disciplinar (inclusive na sua forma interiorizada como a instância do supereu freudiano e nas manifestações daquilo que Freud chamou de masoquismo moral). Pode-se inclusive argumentar que Freud manteve uma atitude igualmente crítica com relação à redução dos determinantes do comportamento a um instinto simples. Por exemplo, em sua Psicologia das massas, ele se refere às concepções de Trotter sobre o instinto social, observando que para esse autor "o instinto gregário seria algo primário, não suscetível de posterior decomposição" (Freud, 1998 [1921], p. 112). Em seguida, dedica-se a criticar bastante incisivamente essa concepção, entre outras coisas, por não haver nela lugar para especificar o papel do condutor ou líder na gênese das massas humanas, que para Freud, desempenha um papel fundamental. Observe-se, contudo, que Freud não está criticando a explicação do comportamento social pelo instinto enquanto tal, mas apenas a sua atribuição à ação de um instinto único que agisse como um determinante isolado para uma ampla gama de comportamentos sociais heterogêneos - ou seja, mais ou menos a mesma crítica que Wilson endereça a Lorenz e ao próprio Freud. Freud afirma a esse respeito, por exemplo: “(...) pode-se demonstrar que é pelo menos provável que o instinto gregário não seja indecomponível, não seja primário, no sentido em que o são os instintos de autoconservação e o instinto sexual" (p. 113; grifo meu).

Voltando, por um momento, à questão da terminologia, cabe ressaltar que, ao longo de toda essa passagem, Freud emprega o termo Trieb para traduzir o termo instinct utilizado por Trotter em seu livro Instincts of the herd in peace and war. E, na passagem citada, emprega Trieb para designar tanto o conceito de "instinto gregário" de Trotter quanto seus próprios conceitos de "instinto de autoconservação" (Selbsterhaltungstrieb) e "instinto sexual" (Sexualtrieb), o que parece indicar que não via grande heterogeneidade entre suas teorias e as teorias biológicas em que o conceito de instinto aparece como uma peça central.

Mas o ponto principal a ser retido de toda essa discussão não é tanto que tipo de teoria do instinto agressivo Freud procura sustentar e em que medida ela está mais 
próxima da biologia do comportamento clássica (Lorenz) ou da sociobiologia (Wilson), mas sim que, seja qual for o caso, se trata de uma teoria biológica do comportamento agressivo. Mais precisamente, trata-se de uma teoria psicológica ou metapsicológica dessa forma de comportamento que reconhece que o mesmo possui um fundamento instintivo e hereditário que não pode ser ignorado na sua elucidação, como Freud não se cansou de afirmar. Com isso, parece cair mais uma razão para se recusar à teoria freudiana dos instintos a plena significação biológica que o termo carrega consigo. Resta, no entanto, uma objeção que o próprio Lorenz reconhece: o conceito de instinto de morte lhe parece um contrassenso do ponto de vista biológico e teria que ser descartado ou justificar-se por outras vias. É preciso verificar, então, o que se pode dizer a esse respeito.

\section{O Trieb сомо INSTINTO DE MORTE}

Há dois aspectos relacionados ao conceito freudiano de instinto de morte que parecem escapar a uma apreciação em termos biológicos, cuja ênfase deveria forçosamente recair, de alguma maneira, em seus aspectos adaptativos que justificassem sua seleção e evolução como uma tendência hereditária. O primeiro seria a manifestação por demais intensa da agressividade alodirigida, excedendo o necessário para a sobrevivência do agressor. Como o próprio Freud empregou o termo (Freud, 1998 [1923], p. 54; 1998 [193o], p. 53, 115; entre outros), pode-se designar esse aspecto do problema como a justificativa de um instinto de destruição (Destruktionstrieb) em ação no comportamento humano. A partir de 1920, Freud abandona a hipótese de que a agressividade seja primariamente sexual ou relacionada à autoconservação. Essas duas classes de instintos ele agora designa conjuntamente como "instintos de vida”, mas relaciona a agressividade, erotizada ou não, à classe dos instintos de morte. Mesmo no caso da agressividade erotizada como sadismo, sua vinculação com a sexualidade seria secundária, e sua origem se daria no contexto da categoria dos instintos de morte:

Partimos da grande oposição entre instintos de vida e instintos de morte. O próprio amor nos apresenta uma segunda polaridade desse tipo, a que medeia entre o amor (ternura) e o ódio (agressão). (...) Desde sempre reconhecemos um componente sádico na pulsão sexual (...). Contudo, como poderíamos derivar do Eros conservador da vida o instinto sádico, que se propõe a causar dano ao objeto? Não cabe supor que esse sadismo é, na verdade, um instinto de morte afastado do eu pelo esforço e influência da libido narcísica, de modo que vem à luz apenas no objeto? (Freud, 1998 [1920], p. 52) 
Como consequência, ele explicitamente abandona a hipótese anterior de que a agressividade e a destrutividade não adaptativas - aquelas que não podiam ser explicadas pela ação do instinto de autoconservação - teriam uma motivação primariamente sexual, ou seja, que toda crueldade seria, em última instância, uma manifestação dos componentes sádicos da sexualidade. Ao contrário, Freud passa a defender a ideia de que é preciso atribuir-lhes uma explicação biológica independente, que é justamente a função que a hipótese dos instintos de morte passa a cumprir na teoria:

Admito que, no sadismo e no masoquismo, tivemos sempre diante de nossos olhos as manifestações do instinto de destruição, dirigidas tanto para fora quanto para dentro, com forte ligação de erotismo; mas já agora considero que não possamos passar por alto a ubiquidade da agressão e da destruição não erótica, nem que deixemos de atribuir-lhes a posição que merecem na interpretação da vida (Freud, 1998 [193o], p. 115-6).

Assim, se na primeira teoria instintual, a agressão era sempre um comportamento secundário ou derivado - dos impulsos para a autoconservação do indivíduo ou da sexualidade - ela agora é redefinida como expressão de "um instinto agressivo especial autônomo" (Freud, 1998 [193o], p. 117), o que é admitido por Freud como uma alteração substancial da teoria psicanalítica geral sobre os motivadores instintivos do comportamento humano e de seus processos mentais. Ainda mais explicitamente, ele afirma logo a seguir que "para tudo o que se segue adoto este ponto de vista: a inclinação agressiva é uma disposição instintiva autônoma e originária do ser humano" (p. 117); trata-se aí de "um instinto agressivo natural dos seres humanos" (p. 118). Essa autonomia instintiva da agressividade, por sua vez, será invocada para explicar os aspectos excessivos, não adaptativos da agressão, aqueles que, pelo menos aparentemente, transcendem as necessidades de sobrevivência e de reprodução do indivíduo. Esse é o primeiro aspecto pelo qual a agressividade se torna destrutividade:

(...) o ser humano não é um ser manso, amável, capaz no máximo de defender-se quando o atacam, mas é lícito atribuir a sua dotação instintiva uma boa quota de agressividade. Em consequência, o próximo não é somente um possível auxiliar e objeto sexual, mas sim uma tentação para satisfazer nele a agressão, explorar sua força de trabalho sem ressarci-lo, usá-lo sexualmente sem seu consentimento, despossuí-lo de seu patrimônio, humilhá-lo, infligir-lhe dor, martirizá-lo e assassiná-lo. (...) Essa agressão cruel aguarda, em geral, uma provocação, ou serve a um propósito diverso, cuja meta também teria podido ser alcançada com mé- 
todos mais benignos. Em circunstâncias propícias, (...) se exterioriza também espontaneamente, desmascara os seres humanos como bestas selvagens que sequer respeitam os membros de sua própria espécie (Freud, 1998 [1930], p. 108; grifo meu).

O segundo aspecto - talvez, o de mais difícil justificação - é o da agressividade autodirigida ou, melhor dizendo, a existência de uma tendência aniquiladora voltada para o próprio organismo, cuja ação "silenciosa", como disse Freud, representaria a mais pura expressão de um instinto de morte; em outras palavras, a expressão de uma tendência interna da vida para retornar ao estado inanimado. É esse o aspecto que foi, em geral, considerado como o mais "mitológico" de toda a teorização freudiana a respeito dos instintos e o mais prontamente recusado pela posteridade psicanalítica, pelo menos na acepção biológica em que foi originalmente formulado. Inicialmente, pode parecer que a autodestrutividade é, ela mesma, uma consequência secundária da internalização da agressão. Freud afirma, por exemplo, que quanto mais um indivíduo sufoque sua agressividade voltada para o exterior "tanto mais severo - e, por isso mesmo, mais agressivo - se torna seu ideal do eu. (...) Quanto mais um ser humano subjugue sua agressão, tanto mais aumentará a inclinação de seu ideal para agredir o eu" (Freud, 1998 [1923], p. 55). Contudo, a sua orientação geral predominante é considerar a autodestrutividade como a expressão primária de um instinto de morte inerente ao organismo e, por conseguinte, à organização do psiquismo. Aagressividade exterior passa a ser assim encarada como uma forma de defesa contra essa destrutividade interna, como uma maneira de canalizar para fora a ação mortífera do instinto: "Mais longe nos levou a ideia de que uma parte do instinto [de morte] se dirigia ao mundo exterior e, então, saía à luz como instinto de agredir e de destruir. (...) se essa agressão direcionada para fora fosse limitada, isso só poderia trazer como consequência um aumento da autodestruição, de resto, sempre presente" (Freud, 1998 [1930], p. 115; grifo meu).

Todas essas características da versão final da concepção freudiana dos instintos ficam claras quando Freud apresenta sinteticamente seus traços definidores, enfatizando ainda sua relação com os fenômenos da vida enquanto tais:

Considerações biológicas pareciam proibir que nos contentássemos com a suposição de uma única classe de instintos. Nos trabalhos de meus últimos anos, (...) considerei uma nova solução para o problema dos instintos. Reuni a conservação de si mesmo e da espécie sob o conceito de Eros e lhe contrapus o instinto de destruição ou de morte, que trabalha sem ruído. O instinto pode ser compreendido, nos termos mais universais, como um tipo de elasticidade do ser vivo, como um 
esforço por repetir uma situação que tenha existido uma vez e foi cancelada por uma perturbação externa. (...) A ação conjugada e contrária de Eros e do instinto de morte fornece, a nosso ver, o quadro geral da vida (Freud, 1998 [1925], p. $5^{3}$; grifo meu).

Fica claro, portanto, que Freud considera a agressividade extrema e a autodestrutividade como expressão de uma constituição biológica que inclui uma tendência para a aniquilação, que ele sintetizou teoricamente na hipótese de um "instinto de morte" (Todestrieb). Resta examinar se esses dois aspectos de sua teoria fazem algum sentido à luz de concepções biológicas do comportamento humano ou se seu sentido tem que ser dado por outra espécie de referencial teórico.

O primeiro aspecto - a agressividade excessiva - é abordado pela sociobiologia de uma forma diferente daquela proposta por Lorenz. Em vez de postular a inexistência de mecanismos inibidores específicos para a ação de um instinto agressivo simples - o qual, por isso, se manifestaria de forma descontrolada no comportamento social humano -, os sociobiólogos colocam a ênfase na própria evolução da sociabilidade como uma adaptação biológica. Em primeiro lugar, considerar a sociabilidade como adaptação biológica não implica desconhecer a especificidade da evolução cultural: o fato de que existam mecanismos inatos, geneticamente determinados, que predisponham o indivíduo humano à agressividade, não quer dizer que a expressão desses determinantes não seja modulada pelo contexto cultural. Afinal, a existência de um fator genético é apenas uma parte da narrativa explicativa do comportamento, uma vez que a expressão desses genes - como um fenótipo comportamental, sobretudo, mas também morfológico, em alguns casos - pode ser modulada e condicionada pelo ambiente (por exemplo, no caso dos chamados "genes induzíveis", cuja transcrição pode responder às mudanças ambientais). Sabidamente, no caso humano, o meio ambiente inclui decisivamente a cultura.

De fato, boa parte da pesquisa contemporânea nas áreas da genética, da epigenética e da biologia molecular em geral se concentra nos mecanismos de expressão gênica (cf. Orphanides \& Reinberg, 2002; Rockman \& Kruglyak, 2006; Raj \& Oudenaarden, 2008). O fundamental, é claro, é a interpretação da informação contida nos genomas, o que só pode ser feito pela análise dos fenótipos a eles relacionados, seja a síntese de uma proteína citoplasmática ou um complexo fenótipo comportamental. Essa é uma relação sempre complexa e multifatorial, que envolve uma multiplicidade de mecanismos epigenéticos de regulação, os quais muito raramente podem ser descritos em termos de uma relação linear, unidirecional e biunívoca entre sequências de genes e caracteres fenotípicos. Daí a importância que o estudo da expressão gênica assume nessa tarefa de interpretação. 
A agressividade, na sua expressão socializada, seria bastante exemplar dessa interação entre genes e ambiente:

As formas específicas de violência organizada não são herdadas. Nenhum gene diferencia a prática da tortura com choques elétricos da tortura com pau-de-arara, a caça de cabeças do canibalismo, o duelo entre heróis do genocídio. Há, ao invés disso, uma predisposição inata à produção de um aparato cultural da agressão, de um modo pelo qual a mente consciente é separada dos processos biológicos não elaborados que os genes codificam (Wilson, 1981 [1978], p. 114).

Por que então a expressão cultural dessa tendência inata à agressividade pode assumir formas excessivas e patológicas, que dariam a impressão da existência de um instinto destrutivo em ação na espécie humana? O ponto central do argumento é a diferença de velocidade entre a evolução biológica e a evolução cultural. Há 50.000 atrás, a totalidade da humanidade vivia como bandos de caçadores-coletores dispersos pelas diversas regiões da Terra. Esse tinha sido seu modo de vida pelas últimas centenas de milhares de anos. O cérebro humano evoluíra adaptado a esse modo de vida social e ao tipo de relação com o ambiente que o mesmo permite ou exige. Com a revolução neolítica iniciada mais ou menos nessa época - o surgimento do pastoreio e da agricultura, com todas as suas consequências sociais, econômicas e ambientais -, houve uma brutal aceleração da evolução cultural humana, a qual não foi, evidentemente, secundada por uma aceleração correspondente da evolução biológica, limitada pelo ritmo das mutações gênicas aleatórias e da seleção posterior das variações vantajosas em termos de sobrevivência e sucesso reprodutivo. Como consequência, o cérebro humano mudou comparativamente muito pouco ao longo do tempo desde então transcorrido, ao passo que o modo de vida da maior parte dos agrupamentos humanos (existem pouquíssimas sociedades de caçadores-coletores sobreviventes hoje em dia) transformou-se enormemente. Dependeríamos ainda, portanto, de nosso cérebro arcaico e paleolítico para agir no mundo contemporâneo. Por isso, formas de comportamento social violento e padrões de reação às ameaças externas (em todos os níveis da organização social) que eram adaptativos naquela situação podem ter-se tornado, hoje, obsoletos e, inclusive, excessivos. Em condições de sobrevivência precárias e de extrema competição por recursos escassos, a seleção natural favoreceria uma reação violenta a uma ameaça externa (outro grupo competindo pelos mesmos recursos, por exemplo) que eliminasse a ameaça com uma considerável margem de segurança. Formas destrutivas de agressão que hoje se apresentam como francamente patológicas (genocídio, por exemplo) encontrariam aí suas origens, sem a necessidade de supor um instinto destrutivo específico, mas mais ou menos com as mesmas consequências. O mesmo aconteceria com 
uma série de características típicas do comportamento humano de uma forma ou de outra relacionada com a agressividade: a desconfiança com relação a estranhos, a tendência a classificar de forma binária os demais em amigos ou inimigos (segundo a máxima "quem não está comigo está contra mim”) etc. Em suma, haveria lugar para a explicação da destrutividade humana, mesmo em suas manifestações mais extremas, no âmbito de uma abordagem biológica e evolucionária tradicional:

(...) a agressão humana não pode ser explicada nem como uma imperfeição devida ao anjo negro, nem como um instinto bestial. Tampouco é um sintoma patológico decorrente da criação em um ambiente cruel. Os seres humanos estão fortemente predispostos a reagir com ódio irracional a ameaças externas e a aumentar sua hostilidade o suficiente para superar a fonte da ameaça com uma margem consideravelmente ampla de segurança. Nossos cérebros parecem estar programados da seguinte maneira: estamos inclinados a classificar as outras pessoas em amigos e estranhos (...). Tendemos a temer profundamente as ações de estranhos e a resolver conflitos pela agressão. Essas regras de aprendizagem muito provavelmente se desenvolveram durante as últimas centenas de milhares de anos de evolução humana e, desse modo, conferiram uma vantagem biológica àqueles que a elas se ajustaram com maior fidelidade. (...) As regras de aprendizagem da agressão violenta estão, em grande parte, obsoletas. Não somos mais os caçadores-coletores que decidem disputas com lanças, flechas e machados de pedra (Wilson, 1981 [1978], p. 119).

As implicações dessa abordagem biológica da destrutividade são menos pessimistas do que poderiam parecer à primeira vista e deixam entrever a possibilidade de que esse componente destrutivo seja controlado:

Mas reconhecer a obsolescência das regras não significa bani-las. Podemos somente encontrar um jeito de contorná-las. Para mantê-las latentes e adormecidas devemos conscientemente seguir aqueles caminhos difíceis e raramente percorridos do desenvolvimento psicológico que conduzem à ascendência sobre a profunda tendência humana de aprender violência e à redução dessa tendência (Wilson, 1981 [1978], p. 120).

Freud, como sabemos, encerrou seu Mal-estar na cultura (Freud, 1998 [193o]) deixando em aberto a possibilidade de Eros subjugar seu "poderoso inimigo" (o instinto de morte), embora ele parecesse, na maior parte das vezes, não acreditar muito nisso e manter uma atitude, no geral, mais pessimista. 
O segundo aspecto da agressão não adaptativa parece bem mais problemático. Como justificar biologicamente uma tendência interna para a autoaniquilação? Como algo assim poderia ter evoluído da maneira prevista pelo modelo darwinista ou neodarwinista? Freud insistiu, em Além do princípio do prazer (Freud, 1998 [1920]), na ideia de que o ciclo vital como um todo tem que ser entendido como um caminho para a morte e que, mesmo os instintos de vida, em última instância, significam que o organismo "só quer morrer à sua maneira", isto é, seguir passo a passo o caminho que a evolução de sua espécie prescreveu para o seu retorno ao estado inanimado. Essa seria a significação mais profunda do conceito de um instinto de morte e sua manifestação mais essencial. É preciso, pois, verificar se essa concepção faz algum sentido de um ponto de vista biológico e evolucionista. Podemos colocar a questão da seguinte maneira: é possível sustentar que haja uma espécie de programação interna para a morte, própria de cada espécie de organismo, a qual teria evoluído sob a ação da seleção natural como qualquer outra de suas características? Ainda que isso possa parecer surpreendente a muitos psicanalistas, a resposta para essa pergunta é, definitivamente, sim.

As questões relativas à duração da vida, ao envelhecimento e à morte têm sido um problema biológico desde antes mesmo do surgimento da teoria darwinista da evolução, embora sua discussão tenha sido assumida e atualizada por esta, como aconteceu com quase todas as questões centrais da biologia. ${ }^{3}$ Freud mesmo discutiu várias dessas teorias em Além do princípio do prazer, inclusive as primeiras abordagens darwinistas do problema, com destaque para aquela de Auguste Weismann, um autor de quem tinha conhecimento desde os tempos de estudante (cf. Schott, 1985). Weismann (1891 [1881]; 1891 [1883]) foi, de fato, um dos primeiros a estudar o problema da morte e do envelhecimento do ponto de vista evolucionário darwinista e sua abordagem - conhecida por Freud - forneceu o ponto de partida para grande parte daquilo que veio depois. No entanto, a abordagem de Weismann ainda apela para conceitos como a "seleção de grupo" e as considerações pelo "bem da espécie”. Essas concepções foram depois descartadas pelo neodarwinismo contemporâneo, que só reconhece a seleção natural como agindo, primariamente, no nível do indivíduo, favorecendo as variações que lhe conferem maior sucesso reprodutivo. Diz Weismann, por exemplo:

3 Podemos citar como exemplo a célebre afirmação de Bichat, em suas Recherches physiologiques sur la vie et la mort (Bichat, $\left.180_{5}[1800]\right)$, de que “a vida é o conjunto das funções que resistem à morte", que antecipa a noção freudiana de um embate entre os instintos de vida e de morte. Também Claude Bernard (1875) afirmara, ao perguntar-se sobre o que é a vida, que a vida é a morte (já que a vida é combustão e a combustão é morte). Ele ainda citava Buffon: "A vida é um minotauro, ela devora o organismo". As referências a Bernard e Buffon também se encontram em Medawar (1957a). 
A morte ocorre porque um tecido desgastado não pode renovar-se para sempre. Indivíduos desgastados não são apenas sem valor para a espécie, mas chegam a ser prejudiciais, pois tomam o lugar daqueles que são sadios. (...) Pela operação da seleção natural, a vida de um indivíduo teoricamente imortal seria abreviada na medida em que isso fosse útil para a espécie (Weismann apud Medawar, 1957b, p. 57).

O argumento desenvolvido por Peter Medawar em dois ensaios sobre o tema do envelhecimento e da morte natural (Medawar, 1957a e 1957b) pode ser entendido como uma atualização das ideias de Weismann. A discussão que se segue é baseada, mais especificamente, no segundo desses ensaios, que é uma retomada do primeiro e apresenta uma versão mais elaborada do argumento ali introduzido. Esse argumento é hoje clássico e exemplar do modo como o problema da morte pode ser abordado de um ponto de vista evolucionista ortodoxo, de uma maneira que não deixa de se aproximar da formulação especulativa freudiana sobre a existência de um instinto de morte. Por isso, é esse argumento que é privilegiado aqui, deixando de lado, por razões de espaço, a vasta literatura sobre o tema dentro da biologia (cf. Williams, 1957; Beutler, 1986; Kirkwood, 1988; Katzman, 1988; entre outros). Ele parte da crítica das concepções de Weismann sintetizadas na passagem citada acima. Essa concepção não explicaria por que os indivíduos e/ou tecidos se desgastam; tampouco explicaria por que esses indivíduos desgastados seriam uma ameaça para os indivíduos sadios, a ponto de deslocá-los de seus habitats (quando tudo parece indicar que se deva esperar o contrário, isto é, que os indivíduos jovens, sadios e vigorosos desloquem os senescentes); e, não menos importante, ela se basearia no conceito vago e desprovido de significação biológica de "benefício da espécie". No entanto, Medawar reconhece o valor das ideias de Weismann, justamente por ele ter sido um dos primeiros a sustentar que "a senescência tenha tido um origem evolucionária bastante ortodoxa" (1957b, p. 58). Seu argumento é complexo e procede por várias etapas que se apresentam resumidamente a seguir.

A primeira consideração é imaginar uma população de indivíduos teoricamente imortais, isto é, cuja vitalidade e fertilidade não diminuam com a passagem do tempo e que apenas morram por causas acidentais externas. Mesmo numa tal população, a participação de cada faixa etária na composição das futuras gerações seria diferenciada: os indivíduos mais jovens teriam uma participação maior pelo simples fato de serem mais numerosos e produzirem mais descendentes, já que a probabilidade de sofrer uma morte acidental aumenta com o tempo. Supondo-se uma população de 1000 indivíduos com uma taxa de mortalidade acidental, aleatória e homogeneamente distribuída de 10\% ao mês, que seja reposta por novos nascimentos na mesma proporção, e supondo que essa população atingiu seu estado de equilíbrio demográfico, haveria faixas 
de etárias compostas em média por 100 indivíduos de menos de um mês de idade, 90 na faixa de 1 a 2 meses, 81 de 2 a 3 meses, e assim por diante, com a soma dessas faixas aproximando-se assintoticamente de 1000.

O segundo passo do argumento é retirar dessa população hipotética a sua condição de imortalidade potencial e supor que, numa certa idade, como resultado de algum fator intrínseco (uma doença hereditária letal, por exemplo), seus indivíduos morram. O efeito desse fator interno sobre a composição futura da população vai depender da idade em que ele é ativado. Se ele entrar em ação muito cedo, os indivíduos portadores dessa característica terão menos chances de se reproduzirem e passá-la a seus descendentes; nesse caso, ela tenderá a desaparecer dessa população. Contudo, se esse mesmo fator manifestar-se mais tardiamente, quando os indivíduos que o portarem já tiverem tido a oportunidade de produzirem um número considerável de descendentes, a tendência para a sua eliminação diminuirá proporcionalmente a esse retardo. Medawar conclui dessas considerações que "a força da seleção natural se enfraquece com o aumento da idade" (Medawar, 1957b, p. 62). Em outras palavras, ela se torna cada vez menos capaz de eliminar uma característica prejudicial, quanto mais esta se manifeste somente depois que os organismos que a possuam já tiverem adentrado bastante em sua idade reprodutiva. Passando dessas considerações hipotéticas para o que realmente ocorre na natureza, o autor prossegue:

Há uma constante e tênue pressão para introduzir novas variações de fatores hereditários em uma população natural, pois a 'mutação', como ela é chamada, é um processo recorrente. Muito frequentemente, tais fatores diminuem a fertilidade ou a viabilidade dos organismos em que eles manifestam seus efeitos; mas pode-se argumentar que, se pelo menos eles os manifestarem suficientemente tarde, a força da seleção estará atenuada demais para se opor ao seu estabelecimento e disseminação (Medawar, 1957b, p. 63).

O terceiro passo é levar em conta que a idade em que um determinado fator hereditário entra em ação é igualmente determinada geneticamente e pode variar ao longo da evolução das espécies - fenômeno biológico conhecido como heterocronia. A heterocronia é uma mudança evolutiva no tempo e ritmo dos acontecimentos que constituem o desenvolvimento, levando a mudanças de tamanho e forma das estruturas orgânicas. Há dois componentes principais: o momento em que um processo começa ou cessa e o ritmo ou velocidade com que o processo ocorre. A chamada Lei de Haeckel, segundo a qual "a ontogênese recapitula a filogênese" - que foi, aliás, tão valorizada e largamente empregada por Freud - é uma hipótese clássica, embora hoje refutada, sobre a heterocronia. No entanto, Gould (1985) promove uma espécie de reabilitação 
parcial da Lei de Haeckel. O erro de Haeckel, segundo ele, não teria sido afirmar a heterocronia - um fenômeno bem conhecido e documentado, essencial para a evolução -, mas sim sustentar: 1) que a heterocronia ocorre só no sentido da aceleração do desenvolvimento (pois, segundo a Lei de Haeckel, o que hoje são características embrionárias dos organismos no passado foi próprio de suas formas adultas); 2) que ela envolve maciçamente o organismo como um todo, quando ela pode afetar independentemente o desenvolvimento de características isoladas. Na verdade, a heterocronia envolve, sobretudo, a aceleração do amadurecimento das células reprodutivas com a manutenção do mesmo ritmo de amadurecimento somático (progênese) ou a manutenção do mesmo ritmo no amadurecimento das células reprodutivas com a desaceleração do desenvolvimento somático (neotenia). Em ambos os casos, o resultado é a chamada pedomorfose, isto é, a ocorrência da reprodução numa forma do organismo que, no passado, correspondeu aos estágios juvenis e pré-reprodutivos do seu desenvolvimento.

No campo psicanalítico, a neotenia foi especialmente valorizada por Lacan, seguindo as ideias do embriologista holandês Lodewjk Bolk, um dos principais teóricos da neotenia como fator de hominização (Menschenwerdung). Bolk (1960; 1961) teria, no entanto, ainda segundo a análise de Gould, cometido o mesmo equívoco de Haeckel, ao supor essa desaceleração como um processo envolvendo sempre a totalidade do organismo. Mesmo assim, feitas as devidas correções, a neotenia é, de fato, essencial na explicação da evolução humana (por exemplo, na manutenção de taxas fetais de crescimento do cérebro após o nascimento). Cabe observar, ainda, que outro dos aspectos da teoria da hominização de Bolk - a prematuração ao nascer - é também enfatizado por Freud desde seus primeiros trabalhos e ainda mais na parte final de sua obra, onde aparece definido como o fator biológico determinante da angústia, da neurose e, por extensão, do desenvolvimento psíquico enquanto tal (Freud, 1998 [1926]).

Nesse processo de alteração do momento de manifestação dos genes (heterocronia), a seleção natural tenderá, então, a adiantar o momento de expressão das variações favoráveis (precessão) e a atrasar o momento de expressão das variações desfavoráveis (recessão). Mas a recessão só pode ser impulsionada pela seleção natural até o ponto em que esse retardamento torne as variações desfavoráveis ou letais inócuas para a eficiência reprodutiva do organismo, quando então ela perde progressivamente o poder de influir sobre as mesmas (atrasá-las ainda mais ou mesmo eliminálas completamente):

Se as diferenças na idade em que ele começa a agir são, de fato, geneticamente determinadas, então a seleção natural deve agir de tal forma a atrasá-lo, pois aqueles em que a idade de desencadeamento é relativamente tardia terão tido, em média, um número maior de descendentes do que aqueles que são afligidos 
por ele relativamente cedo e terão então propagado mais amplamente quaisquer fatores hereditários que sejam responsáveis pelo atraso. Mas, à medida que a idade de desencadeamento se aproxima do final do período reprodutivo, a ação direta da seleção no sentido de atrasá-lo necessariamente se desvanecerá (Medawar, 1957b, p. 66; grifo do autor).

Essas considerações permitem a formulação do que o autor considera um teorema geral a respeito dessa questão, afirmando a tendência evolutiva para a recessão dos genes deletérios e para a precessão das variações favoráveis:

Se fatores hereditários atingem sua expressão manifesta em alguma idade intermediária da vida; se a idade dessa expressão manifesta é variável; e se essas variações são elas mesmas herdáveis; então a seleção natural agirá de tal forma a forçar o adiamento da idade da expressão desses fatores que sejam desfavoráveis e, de forma correspondente, a apressar os efeitos daqueles que sejam favoráveis - uma recessão e uma precessão, respectivamente, dos efeitos variáveis dos genes sobre a idade. É isso que eu quero dizer ao afirmar que a senescência é um processo autorreforçador (Medawar, 1957b, p. 67-8).

Assim, o próprio modo como a evolução ocorre faz do envelhecimento uma espécie de potência autônoma dentro do organismo ("um processo autorreforçador", como diz Medawar), pelo simples fato de que a seleção natural é incapaz de eliminar variações desfavoráveis, uma vez que elas se manifestem relativamente tarde na vida. "Tarde", aqui, significa: quando a idade reprodutiva já esteja bem avançada ou perto do seu final ou, em todo caso, quando ela já permitiu ao organismo a produção de um número estatisticamente significativo de descendentes. A partir desse momento, todo tipo de mazelas podem afligir o organismo, sem que isso faça mais diferença em termos de sua adaptação (isto é, de sua capacidade de produzir descendentes e fazer representar os seus genes no pool genético das gerações futuras). São essas mazelas, esses efeitos deletérios dos genes prejudiciais que não mais podem ser eliminados que levam o organismo, finalmente, à morte. Então, de fato, pode-se perfeitamente falar de uma programação genética interna para a morte dentro do quadro de uma explicação evolucionária darwinista ortodoxa, como a que resumimos aqui. Se for isso que o conceito freudiano de instinto de morte significa, como parece ser o caso - ele implica que os organismos morram, essencialmente, por causas internas, como disse Freud, e apenas acidentalmente por causas externas -, então não haveria grandes dificuldades, muito menos uma impossibilidade de princípio, para reconstruir o conceito em termos compatíveis com o conhecimento biológico atualmente disponível. 
$\mathrm{O}$ argumento de Medawar tem a vantagem de efetivamente fornecer uma explicação de por que os organismos se desgastam com o tempo, ao contrário do de Weismann, de cuja crítica ele parte e que apenas assume isso como um dado. Ele também dá um sentido mais preciso à tese de Weismann - também mencionada e discutida por Freud - de que os indivíduos são apenas os depositários transitórios de um plasma germinativo imortal que se transmite de geração em geração. Mas, ao mesmo tempo, ele consiste, reconhecidamente, numa retomada e numa atualização das ideias de Weismann no contexto do darwinismo renovado pela teoria sintética da evolução, com sua integração entre teoria evolucionária e genética e sua ênfase na seleção natural como mecanismo fundamental da evolução. Ou seja, ele situa uma das teorias inspiradoras do conceito freudiano de instinto de morte no contexto do que veio a ser chamado de neodarwinismo e que é, até hoje, um dos paradigmas dominantes nas ciências da vida. Diz ele:

Eu acho que deve estar claro que a origem e evolução da senescência não é um mistério genético insolúvel (...). Então talvez eu tenha sido indevidamente desrespeitoso com a memória de Weismann ao ridicularizar suas conjeturas sobre a senescência. Num esboço bem amplo, elas não eram provavelmente errôneas, pelo menos na medida em que a seleção natural era reconhecida como o instrumento de sua origem e perpetuação (Medawar, 1957b, p. 70).

Talvez o mesmo pudesse ser dito das próprias teorias de Freud envolvendo um instinto de morte, uma teoria que ele desenvolveu com pleno conhecimento das teses de Weismann - como o revelam as diversas referências em Além do princípio do prazere que, portanto, foi formulada também com pleno conhecimento das implicações e das exigências de uma abordagem biológica informada pela teoria darwinista da evolução, ao contrário do que diversas críticas posteriores quiseram fazer crer. Afastar essas objeções de princípio é uma maneira de abrir caminho para as aproximações efetivas, embora não muito frequentes, que já se podem encontrar entre teorias biológicas mais específicas e aspectos da concepção freudiana do instinto de morte. ${ }^{4}$

4 Um tema biológico comumente relacionado com o instinto de morte freudiano é a apoptose (Hoffman, 2004), uma das formas de morte celular programada. Kernberg (2009, entre outros) é, no entanto, um dos poucos autores dentro do campo psicanalítico a defender uma interpretação biológica dos fenômenos clínicos destrutivos e autodestrutivos, embora sugira o deslocamento do foco dessa discussão da teoria dos instintos para a teoria dos afetos. 


\section{Considerações finais}

O objetivo aqui foi recensear algumas abordagens biológicas do comportamento instintivo e dos fatores comportamentais hereditários, a fim de recolocar em discussão e desenvolver uma crítica sistemática e fundamentada à tendência de interpretar a teoria freudiana dos instintos (Triebe) como desprovida de uma significação biológica literal ou, em todo caso, como incompatível e até mesmo oposta ao conhecimento biológico disponível. Os argumentos aqui apresentados não implicam por si sós a adesão a nenhuma abordagem biológica específica do comportamento humano ou animal e, tampouco, entram no mérito da avaliação de alguns desdobramentos ideológicos de teorias ainda polêmicas, como é o caso emblemático da sociobiologia. 5 No entanto, evidências significativas a favor de uma interpretação biológica das concepções freudianas sobre sexualidade, agressão e autodestrutividade podem ser encontradas nas correntes teóricas mais estreitamente ligadas ao paradigma darwinista e neodarwinista da biologia contemporânea (o que não quer dizer que não possam ser encontradas em outras tendências que, não obstante, não foram exploradas aqui). ${ }^{6}$ Mas o próprio fato de que essas evidências de compatibilidade aparecem onde elas talvez fossem menos esperadas - a saber, em teorias de orientação neodarwinista que privilegiam a seleção a posteriori de características adaptativas favorecendo a sobrevivência e a reprodução de certos indivíduos - reforça o argumento que se procurou apresentar aqui: o da viabilidade de uma interpretação biológica do Trieb freudiano, quer se trate de um instinto sexual, de um instinto de destruição ou de um instinto de morte.

Em suma, tratou-se, sobretudo, de tentar dissipar a ideia - às vezes, apressadamente afirmada - de que a teoria psicanalítica, pelo seu próprio conteúdo, contradiria o conhecimento biológico e teria que ser pensada independentemente do mesmo e, até mesmo, em oposição a ele. Embora seja possível encontrar leituras de Freud que reconheçam a importância teórica de uma interpretação biológica de seus conceitos, essas leituras são, em geral, circunspectas e restritivas quanto a essa possibilidade

5 Para uma avaliação ponderada dos aspectos científicos e ético-políticos da sociobiologia, assim como de algumas reivindicações exageradas que são feitas em nome dessa teoria, cf. Ruse (1983).

6 Outra possibilidade de aproximação, por exemplo, seria por intermédio dos modelos teóricos biossemânticos em biologia, que constituem um paradigma alternativo ao modelo neodarwinista e definem o próprio fenômeno da vida como produção de sentido (cf. Emmeche \& El-Hani, 2000). De fato, Freud adota uma epistemologia naturalista e, ao mesmo tempo, propõe uma concepção de explicação psicológica que atribui uma significação causal a relações de sentido, o que pressupõe alguma espécie de naturalização da própria noção de sentido. Por outro lado, há autores (Álvares, 2005) que já procuraram aproximar a psicanálise da semiótica morfodinâmica de Jean Petitot (PetitotCorcorda, 1985; Petitot, 1992), que propõe, justamente, uma abordagem do problema do sentido em termos compatíveis com o naturalismo científico. 
(Barbosa \& Santos, 2005), e a atitude mais frequente, em todo o caso, continua ser a de rejeição (Delouya, 1992; Laplanche, 1993; 1999).

Em todo o caso, essa foi uma tentativa de esclarecer os termos do debate, uma vez que essas reivindicações de heterogeneidade, de independência e de incompatibilidade que provêm do campo psicanalítico são frequentemente feitas com um conhecimento bastante restrito do que as teorias biológicas afirmam ou implicam. Como se viu, uma opinião diversa pode ser encontrada facilmente nas ciências biológicas: Lorenz via semelhanças entre sua visão da agressividade e a visão psicanalítica, embora ele explicasse de modo distinto os mesmos fenômenos, por exemplo, quando explicava a agressividade patológica pela inexistência de mecanismos inibidores para a agressão intraespecífica, e não pela hipótese da existência de um instinto específico de destruição. Já Wilson coloca Lorenz e Freud no mesmo grupo de teorias biológicas da agressão que ele procura criticar, mas em nenhum momento parece duvidar da significação biológica dos conceitos freudianos.

Para Freud, a necessidade de fundamentar biologicamente sua teoria dos instintos - e, com isso, as explicações psicológicas que esta propicia no campo de atuação da psicanálise - sempre foi afirmada com muita convicção e, ao que parece, com bastante conhecimento do que estava em jogo nessa afirmação (cf. Simanke, 2010). Assim, no momento mesmo de introduzir e justificar sua nova teoria dos instintos, ele manifesta sua expectativa de que o desenvolvimento do conhecimento biológico possa tornar essa teoria menos obscura e menos especulativa:

\begin{abstract}
(...) deve-se deixar bem claro que a incerteza de nossa especulação foi muito aumentada pela necessidade de fazer empréstimos da ciência da biologia. A biologia é, verdadeiramente, um território de possibilidades ilimitadas. Podemos esperar dela os esclarecimentos mais surpreendentes e não podemos sequer adivinhar quais respostas ela nos dará, em algumas décadas, às questões que nós agora lhe colocamos (Freud, 1998 [1920], p. 58; grifo meu).
\end{abstract}

A sugestão que fica das análises feitas aqui é, ao menos dessa vez, seguir a orientação do criador da psicanálise e verificar qual é a contribuição que a biologia - hoje muito mais desenvolvida do que nos tempos de Freud - tem a oferecer para a resolução dos problemas teóricos, empíricos e clínicos dos quais a psicanálise se ocupa.\$ 


\title{
O Trieb de Freud gomo instinto 2: agressividade e autodestrutividade
}

Agradecimentos: O autor gostaria de agradecer o apoio do CNPq, sobre a forma de Bolsa de Produtividade em Pesquisa concedida ao projeto Psicanálise, ciência e neurociência: Freud e a epistemologia das ciências da mente contemporâneas, do qual este artigo apresenta uma parte dos resultados. Gostaria também de agradecer aos anônimos revisores de Scientiae Studia, cujos pareceres foram exemplares de uma crítica construtiva que efetivamente contribui para o aperfeiçoamento do trabalho.

\section{Richard Theisen Simanke}

Departamento de Psicologia, Instituto de Ciências Humanas, Universidade Federal de Juiz de Fora, Minas Gerais, Brasil. richardsimanke@uol.com.br

\section{Freud's Trieb as instinct 2: aggression and self-destructiveness}

\begin{abstract}
AB STRACT
Freud's concept of drive or instinct (Trieb) has been widely acknowledged as one of psychoanalysis' most fundamental concepts. However, its meaning is still a matter of controversy. It was originally defined by Freud in a biological or quasi-biological sense, but its reception in many different post-Freudian traditions has often tended to reject this early epistemological affiliation. One sign of this theoretical reorientation has been to refuse the translation of Trieb as "instinct" and to favor instead the neologism "pulsion", which has French origins and became common in the psychoanalytic literature written in many neo-Latin languages, including Portuguese. The objective of this paper is to criticize this trend. For that, the main arguments usually presented against a biological view of Freud's Trieb are discussed, namely: 1) the terminological alternative between the German words Trieb and Instinkt and how these terms are employed by Freud; 2) Freud's critique of the reduction of human sexuality to the reproductive function; 3) the concept of Todestrieb (death instinct or death drive), formulated by Freud around 1920 and central in the last stage of his thought. It is argued that these formulations do not preclude a biological interpretation of the concept of Trieb. Such interpretation, in turn, opens the way for dialogue between psychoanalysis and biology, a dialogue which was also emphatically and explicitly supported by Freud. Some hypotheses in the field of neo-Darwinian evolutionary biology and sociobiology are discussed and it is argued that they are compatible, if not convergent, with Freud's views. The first part of the paper was an introduction to this issue and also approached the problem of the relationship between sexuality and reproduction in psychoanalysis and biology. This second part is dedicated to the problem of aggression and self-destructiveness in these two fields of knowledge.
\end{abstract}

KEYwords • Freud. Psychoanalysis. Metapsychology. Instinct. Drive. Biology. Death. Sexuality. 


\section{REFERÊNGIAS BIBLIOGRÁFICAS}

Álvares, C. Le statut de la pulsion dans la sémiotique narrative morphodynamique. Semiotica, ${ }_{157}$, p. $431-51,2005$.

Barbosa, M. N. P. \& Santos, M. A. Considerações sobre a dimensão biológica do conceito de pulsão em Freud. Psicologia: Reflexão e Crítica, 18, 2, p. 162-70, 2005.

Barnett, S. A. The ontogeny of behavior and the concept of instinct. In: Karczmar, A. G. \& Eccles, J. C. (Ed.). Brain and human behavior. Berlin: Springer Verlag, 1972. p. 377-92.

Bateson, P. Taking the stink out of instinct. In: Rose, H. \& Rose, S. (Ed.). Alas, poor Darwin: arguments against evolutionary psychology. London: Jonathan Cape, 2000. p. 157-73.

Bernard, C. Définition de la vie, les théories anciennes et la science moderne. Revue des Deux Mondes, 3 , 9, p. 326-49, 1875 .

Beutler, E. Planned obsolescence in humans and in other biosystems. Perspectives in Biology and Medicine, 29, p. 175-9, 1986.

Bichat, X. Recherches physiologiques sur la vie et la mort. 3.ed. Paris: Brosson \& Gabon, $18 \circ 5$ [1800].

Blanco, I. M. The four antinomies of the death instinct. International Journal of Psychoanalysis, 86, 5 , p. $14,63-76,2005$.

Bolk, L. La genèse de l'homme. Arguments, 18, p. 3-15, 1960.

Le problème de la genèse humaine. Revue Française de Psychanalyse, 25, 2, p. 24,3-79, 1961.

BRIGANDT, I. The instinct concept of the early Konrad Lorenz. Journal of the History of Biology, 38, p. 571608,2005 .

Deloura, D. O biológico em Freud: "corpo estranho" ou heresia? Percurso: Revista de Psicanálise, 4, p. 39$45,1992$.

EL-Hani, C. N. \& Videira, A. A. P. (Ed.). O que évida? Para entender a biologia do século XXI. Rio de Janeiro: Relume-Dumará, 2000.

Emmeghe, C. \& El-Hani, C. N. Definindo vida. In: El-Hani, C. N. \& Videira, A. A. P. (Ed.). O que évida? Para entender a biologia do século XXI. Rio de Janeiro: Relume-Dumará, 2000. p. 31-56.

Evered, D. \& Whelan, J. (Ed.). Research and the ageing population. Chichester: John Wiley, 1988.

Foxe, A. N. Critique of Freud's concept of a death instinct. Psychoanalytic Review, 3o, p. 417-27, 194.3.

Frank, G. Triebe and their vicissitudes: Freud's theory of motivation reconsidered. Psychoanalytic Psychology, 20, 4, p. 691-7, 2003.

Freud, S. Pulsiones y destinos de pulsión. In: Strachey, J. \& Freud, A. (Ed.). Obras completas de Sigmund Freud. Traducción J. L. Etcheverry. Buenos Aires: Amorrortu, 1998 [1915]. v. 12, p. 105-34.

. Más allá del principio de placer. In: Strachey, J. \& Freud, A. (Ed.). Obras completas de Sigmund Freud. Traducción J. L. Etcheverry. Buenos Aires: Amorrortu, 1998 [1920]. v. 18, p. 1-62.

. Psicología de las masas y análisis del yo. In: Straghey, J. \& Freud, A. (Ed.). Obras completas de Sigmund Freud. Traducción J. L. Etcheverry. Buenos Aires: Amorrortu, 1998 [1921]. v. 18, p. 63-136. . El yo y el ello. In: Strachey, J. \& Freud, A. (Ed.). Obras completas de Sigmund Freud. Traducción J. L.

Etcheverry. Buenos Aires: Amorrortu, 1998 [1923]. v. 19, p. 1-66.

. Presentación autobiográfica. In: Strachey, J. \& Freud, A. (Ed.). Obras completas de Sigmund Freud.

Traducción J. L. Etcheverry. Buenos Aires: Amorrortu, 1998 [1925].v. 20, p. 1-70.

. Inhibición, síntoma y angustia. In: Strachey, J. \& Freud, A. (Ed.). Obras completas de Sigmund Freud.

Traducción J. L. Etcheverry. Buenos Aires: Amorrortu, 1998 [1926]. v. 20, p. 71-161.

. El mal-estar en la cultura. In: Strachey, J. \& Freud, A. (Ed.). Obras completas de Sigmund Freud.

Traducción J. L. Etcheverry. Buenos Aires: Amorrortu, 1998 [193o].v. 2, p. 57-14,O.

Fromm, E. The anatomy of human destructiveness. New York: Holt, Rinehart and Winston, ${ }_{197} 3$.

Gould, S. J. Ontogeny and phylogeny. Cambridge: Belknap Press, 1985. 


\section{O Trieb de Freud como instinto 2: agressividade e autodestrutividade}

Griffiths, P. E. Instinct in the "5os: the British reception of Konrad Lorenz's theory of instinctive behavior. Biology and Philosophy, 19, 4, p. 609-31, 2004.

Hoffman, T. Revival of the death instinct: a view from contemporary biology. Neuropsychoanalysis, 6, 1 , p. 63-75, 2004.

Karczmar, A. G. \& Eccles, J. C. (Ed.). Brain and human behavior. Berlin: Springer Verlag, 1972.

Katzman, R. Normal ageing and the brain. News in Physiological Science, 3, p. $197^{-200, ~} 1988$.

KeRnBerg, O. The concept of death drive: a clinical perspective. International Journal of Psychoanalysis, 90, p. 1009-23, 2009.

Kirkwood, T. B. The nature and causes of ageing. In: Evered, D. \& Whelan, J. (Ed.). Research and the ageing population. Chichester: John Wiley, 1988. p. 193-206.

Laplanche, J. Le fourvoiement biologisant de la sexualité chez Freud. Paris: Institut Synthélabo, 1993. La sexualité humaine: biologisme et biologie. Paris: Institut Synthélabo, 1999.

Lehrman, D. S. A critique of Konrad Lorenz's theory of instinctive behavior. Quarterly Review of Biology, 28,4, p. $337^{-63}, 195^{3 .}$

Lorenz, K. L'agression: une histoire naturelle du mal. Paris: Flammarion, 1969 [1963].

McCaugh, J. (Ed.). Psychobiology: behavior from a biological perspective. New York: Academic Press, 1971.

Medawar, P. The uniqueness of the individual. New York: Basic Books, 1957. . Old age and naturald death. In: . The uniqueness of the individual. New York: Basic Books, 1957 a. p. $17^{-4} 4^{3}$.

. An unsolved problem of biology. In: The uniqueness of the individual. New York: Basic Books, 1957b. p. 44-70.

Moltz, H. Contemporary instinct theory and the fixed action pattern. Psychological Review , 72, 1, p. $27-47$, 1965 .

Murta, C.; Bocga, F. V. \& Simanke, R. T. (Org.). Psicanálise em perspectiva II. Curitiba: Editora CRV/ Capes, 2010.

Orphanides, G. \& Reinberg, D. A unified theory of gene expression. Cell, 108, 4, p. 4.39-51, 2002.

Ретітот, J. Physique du sens: de la théorie des singularités aux structures sémio-narratives. Paris: Éditions du CNRS, 1992.

Petitot-Corcorda, J. Morphogenèse du sens. Paris: PUF, 1985. v. 1.

Poulton, E. B.; Schönland, S. \& Shipley, A. E. (Ed.). Essays upon heredity and kindred biological problems. Oxford: Clarendon Press, 1891.

RaJ, A. \& Oudenaarden, A. Nature, nurture, or chance: stochastic gene expression and its consequence. Cell, 135,2, p. 216-26, 2008.

Richards, R. J. The innate and the learned: the evolution of Konrad Lorenz's theory of instinct. Philosophy of the Social Sciences, 4, 2, p. 111-33, 1974.

Rogkman, M. V. \& Kruglyak, L. Genetics of global gene expression. Nature Reviews: Genetics, 7, p. 862-72, 2006.

Rose, H. \& Rose, S. (Ed.). Alas, poor Darwin: arguments against evolutionary psychology. London: Jonathan Cape, 2000.

Ruse, M. Sociobiologia: senso ou contra-senso. Belo Horizonte: Itatiaia/Edusp, 1983.

Sснотт, H. Eine Diskussionsbemerkung zur Weismann-Rezeption: Die Notiz Sigmund Freuds über Weismann. Freiburger Universitätsblätter, 87/88, p. 133-4, 1985.

Simanke, R. T. Psicanálise e biologia: um retorno às fontes freudianas. In: Murta, C.; Bocca, F. V. \& Simanke, R. T. (Org.). Psicanálise em perspectiva II. Curitiba: Editora CRV/Capes, 2010. p. 17-20.

O Trieb de Freud como instinto 1: sexualidade e reprodução. Scientiae Studia, 12, 1, p. 73-95, 2014.

Slavin, M. O. \& Kriegman, D. Freud, biology, and sociobiology. American Psychologist, 43, 8, p. 658-61, 1988. 
Strachey, J. \& Freud, A. (Ed.). Obras completas de Sigmund Freud. Traducción J. L. Etcheverry. Buenos Aires: Amorrortu, 1998. 24v.

Weismann, A. The duration of life. In: Poulton, E. B.; Schönland, S. \& Shipley, A. E. (Ed.). Essays upon heredity and kindred biological problems. Oxford: Clarendon Press, 1891 [1881]. p. 1-66.

. Life and death. In: Poulton, E. B.; Schöntand, S. \& Shipley, A. E. (Ed.). Essays upon heredity and kindred biological problems. Oxford: Clarendon Press, 1891 [1883]. p. 107-62.

Whalen, R. E. The concept of instinct. In: MaCaugh, J. (Ed.). Psychobiology: Behavior from a biological perspective. New York: Academic Press, 1971. p. $5^{3-72 .}$

Wilbur, G. B. Some problems presented by Freud's life-death instinct theory (1). American Imago, 2, p. 134-96, 19411a.

. Some problems presented by Freud's life-death instinct theory (2). American Imago, 2, p. 209-65, 1941, 1 .

Williams, G. Pleiotropy, natural selection, and the evolution of senescence. Evolution, 11, p. 398-411, 1957 .

Wilson, E. O. Da natureza humana. São Paulo: Queiroz, 1981 [1978]. 